\title{
THE THERMAL EVOLUTION OF CRATONIC LOWER CRUST/UPPER MANTLE: EXAMPLES FROM EASTERN AUSTRALIA AND SOUTHERN AFRICA.
}

\author{
N.J. Pearson ${ }^{(1)} ;$ S.Y. O'Reilly ${ }^{(1)}$ and W.L. Griffin ${ }^{(2)}$.
}

(1) School of Earth Sciences, Macquarie University, Sydney NSW 2109, Australia; (2) Div. Expl. Geosciences, CSIRO, North Ryde NSW 2113, Australia.

\begin{abstract}
Xenolith suites of inferred lower crustal origin occur in kimberlites and basaltic rocks near the eastern margin of the Australian craton (EMAC) and in kimberlites marginal to or off the southern margin of the Kaapvaal craton, southern Africa (SAF). Mafic rock types are dominant and include garnet websterites (garnet+clinopyroxene+orthopyroxene \pm spinel), mafic granulites (garnet+clinopyroxene+plagioclase \pm orthopyroxene \pm amphibole \pm quartz \pm scapolite trutile), kyanite-bearing mafic granulites (garnet+clinopyroxene+kyanite+plagioclase torthopyroxene \pm quartz \pm scapolite \pm rutile) and eclogites (garnet+clinopyroxene+rutile \pm quartz \pm kyanite). Both xenolith suites preserve reaction microstructures and mineral chemistry evidence for the transformation of igneous assemblages and microstructures to granoblastic granulite and eclogite: these features are interpreted as reflecting progressive cooling (Griffin $e t$ al., 1990; Pearson et al., 1991; Pearson \& O'Reilly, 1991).
\end{abstract}

Geothermobarometry on these xenoliths yields the ambient temperature at each depth at the time of entrainment in the magma and can be used to construct a paleogeotherm. P-T data obtained from the EMAC mafic $x$ enoliths define a curve stretching from $800^{\circ} \mathrm{C}$ at $10 \mathrm{kbar}$ to $1020^{\circ} \mathrm{C}$ at $22 \mathrm{kbar}$ (Fig. 1). This curve is displaced c. $150^{\circ} \mathrm{C}$ below the xenolith-derived geotherm for the lower crust/upper mantle beneath the Phanerozoic Tasman Fold Belt, eastern Australia (O'Reilly \& Griffin, 1985) and indicates a distinct thermal variation away from the craton boundary. Despite preserving evidence of cooling toward a conductive steady state geotherm, the shape of the EMAC geotherm retains an advective heat flow signature.

The geotherm constructed from the southern Africa mafic xenoliths is less tightly constrained with a greater scatter in P-T data (Fig. 1). The data are distributed in a band from 650 to 750 ${ }^{\circ} \mathrm{C}$ at $10 \mathrm{kbar}$ to c. $1000^{\circ} \mathrm{C}$ at $20 \mathrm{kbar}$, with a range in temperature of up to $150^{\circ} \mathrm{C}$ at a given pressure. The lower limits of the P-T band overlap with the P-T field derived from the Lesotho xenolith suite (Griffin et al., 1990), but are still well above the cratonic geotherm defined by garnet peridotites (e.g. Finnerty \& Boyd, 1987).

These large lateral variations in temperature at the base of the crust and the definition of distinct thermal regimes related to tectonic environment are significant to the relative stability of eclogite and granulite mineral assemblages. The restriction of lower-crustal eclogite suites to craton or craton-margins, and their apparent absence from younger terranes with elevated geotherms (e.g., south-east Australia) is a consequence of this temperature difference.

A stratigraphy based on the P-T data from the EMAC and SAF mafic xenoliths indicates the interlayering or coexistence of eclogite and granulite over a depth range of $30-70 \mathrm{~km}$ in both cratons. Thermal relaxation toward a steady-state conductive geotherm should result in the progressive re-equilibration of mafic igneous intrusions around the crust/mantle boundary, under granulite facies conditions. As cooling proceeds, an increasing proportion of mafic compositions will react to produce eclogite facies assemblages. Reactions progress is dependent not only on P-T conditions but on bulk compositional constraints and reaction kinetics. The wide range in bulk compositions from both the EMAC and SAF xenolith suites is a major factor in controlling the proportions of granulite to eclogite. The role of kinetic factors in the granulite to eclogite transition is emphasized by the preservation of reaction microstructures, chemical zoning and the greater scatter of P-T data points with decreasing temperature, due to increasingly sluggish reaction rates. 


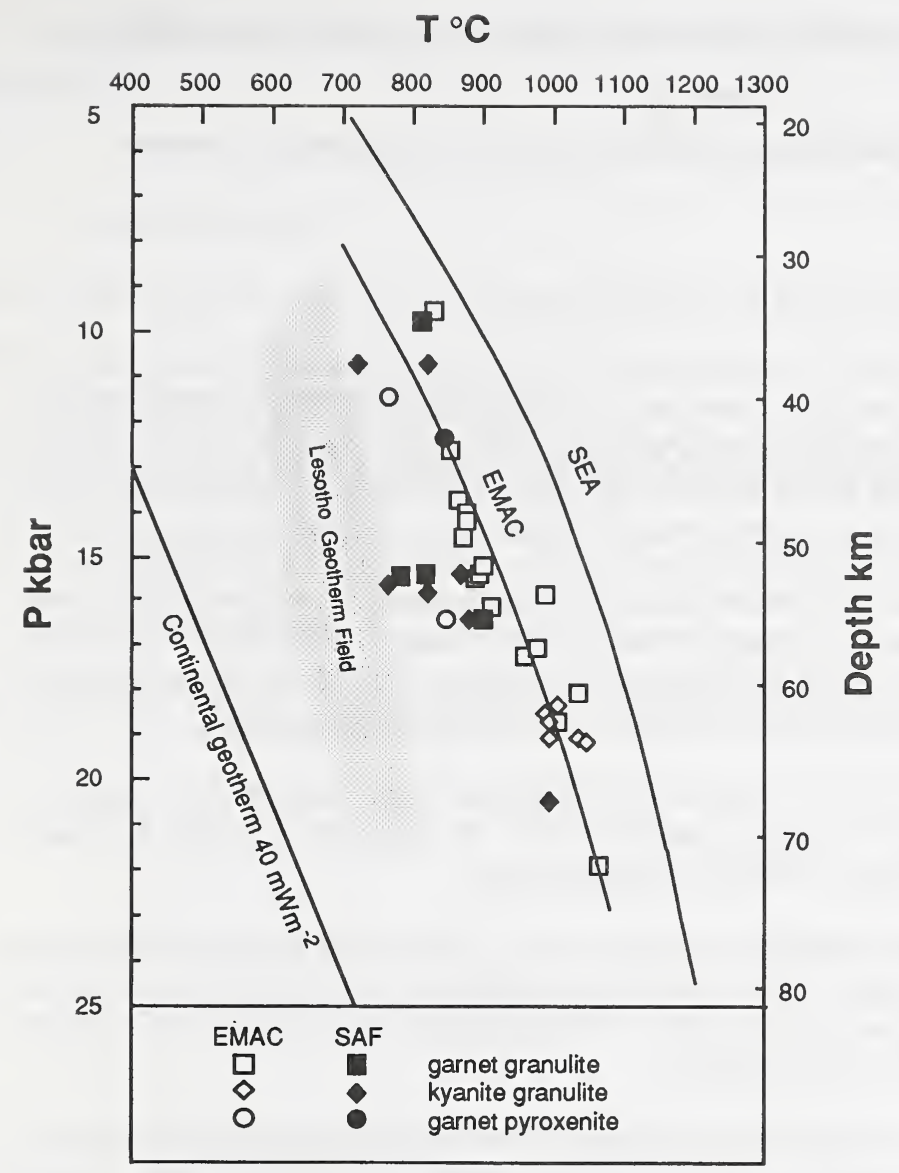

Fig.1: Pressure (P) temperature $(T)$ - depth profile for xenoliths from the eastern margin of the Australian craton (EMAC) and southern Africa (SAF). Also shown are the xenolith-derived geotherm for south eastern Australia (SEA; O'Reilly \& Griffin, 1985) and the Lesotho Geotherm Field (Griffin et al., 1990). The continental geotherm $\left(40 \mathrm{mWm}^{-2}\right)$ is taken from Pollack \& Chapman (1977). Details of the thermobarometric methods used are presented in Pearson et al., (1991).

\section{REFERENCES}

Finnerty, A.A. \& Boyd, F.R., 1987. Thermobarometry for garnet peridotites: basis for the determination of thermal and compositional structure of the upper mantle. in: Nixon, P.H., Ed., Mantle Xenoliths, Wiley, London, p.381-402.

Griffin, W.L., O'Reilly, S.Y. and Pearson, N.J., 1990. Eclogite stability near the crust-mantle boundary. in: Carswell, D.A., Ed, Eclogite Facies Rocks, Blackie, Glasgow, p.291-314.

O'Reilly, S.Y. and Griffin, W.L., 1985. A xenolith-derived geotherm for southeastern Australia and its geophysical implications. Tectonophysics, 111, 41-63.

Pearson, N.J. and O'Reilly, S.Y., 1991. Thermobarometry and P-T-t paths: the granulite to eclogite transition J. Metamorphic Geology, in press.

Pearson, N.J., O'Reilly, S.Y. and Griffin, W.L., 1991. The granulite to eclogite transition beneath the eastern margin of the Australian craton. European Journal of Mineralogy, in press.

Pollack, H.N. \& Chapman, D.S., 1977. On the regional variation of heat flow, geotherms and lithospheric thickness. Tectonophysics, 38, 279-296. 